\title{
Pengaruh Kebijakan Dividen Dan Profitabilitas Terhadap Harga Saham Emiten LQ 45 Tahun 2009-2018
}

\author{
Ni Putu Laksmi Narayanti ${ }^{1}$ \\ Fakultas Ekonomi dan Bisnis \\ Universitas Udayana, Indonesia \\ Email: laksminarayanti@gmail.com
}

\author{
Gayatri ${ }^{2}$ \\ Fakultas Ekonomi dan Bisnis \\ Universitas Udayana, Indonesia
}

\begin{abstract}
ABSTRAK
Penelitia ini bertujuan untuk mendapatkan bukti empiris hubungan kebijakan dividen dan. Profitabilitas terhadap harga saham. Populasi yang digunakan merupakan perusahaan yang menjadi bagian LQ-45 periode 2009 - 2018, alasannya emiten yang terdapat pada indeks ini cenderung mendistribusikan deviden dan meiliki likuiditas perdangan tinggi. Teknik purposive sampling merupakan teknik yang digunakan dalam penentuan sampel dan total perusahaan amatan sebanyak 6 perusahaan per tahun. Analisis Regresi Linear Berganda digunakan sebagai teknik uji hipotesis. Hasil membuktikkan bahwa kebijakan deviden memberikan pada harga saham dan profitabilitas yang diproksikan dengan ROA berpengaruh positif pada harga saham perusahaan
\end{abstract}

Kata Kunci: Kebijakan Dividen; Harga Saham; Profitabilitas; LQ45.

\section{The Influence Of Dividend Policy On LQ45 Emitent Stock} Price 2009-2018

\section{ABSTRACT}

This study aims to obtain empirical evidence of the relationship between dividend policy and profitability on the o stock prices. The population in this study are companies registered in the LQ-45 period 2009 - 2018, the reason issuers contained in this index tend to distribute dividends and have high trade liquidity. The sampling technique in this study was purposive sampling and the total observation companies were 6 sample companies. Data analysis techniques using Multiple Linear Regression Analysis. As the results, the devidend policy brings a possitive effect on the stock prices, and the profitability that has been proxied by ROA also brings a possitive effect on the company's stock price.

Keywords: $\quad$ Devidend Policy; Stock Prices; Profitability; LQ45.

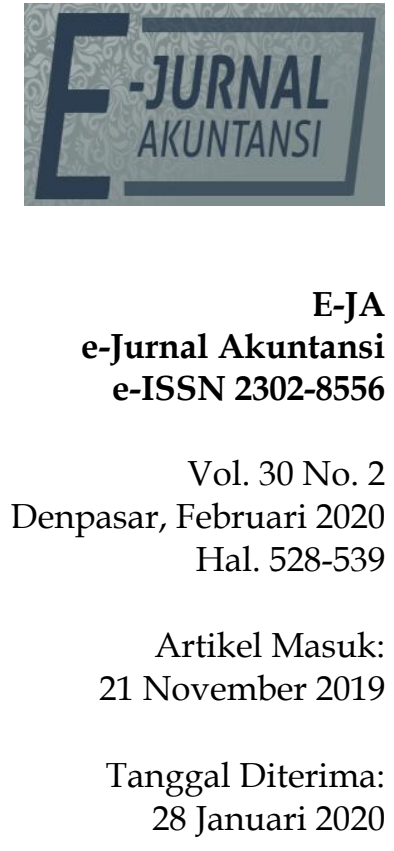

28 Januari 2020 


\section{PENDAHULUAN}

Pasar modal merupakan wahana menghimpun dana, pembiayaan usaha serta pengalokasian investasi yang efisien. Pasar modal berfungsi sebagai sumber penghimpun dana atau sebagai sarana investasi baik berupa saham, obligasi, reksadana, istrumen derivatif maupun instrumen keuangan lainnya (Andiani, 2018).Saham merupakan salah satu instrumen keuangan yang paling dominan diperdagangkan di pasar modal. Saham juga merupakan jenis efek yang paling sering digunakan oleh perusahaan untuk memperoleh dana dari masyarakat dan juga merupakan jenis yang paling populer di pasar modal.

Bursa Efek Indonesia (BEI) adalah pihak yang menyelenggarakan dan menyediakan sistem dan atau sarana untuk mempertemukan penawaran jual dan beli saham pihak-pihak lain dengan tujuan memperdagangkan saham di antara mereka.Pada umumnya suatu perusahaan khususnya perusahaan go public cenderung memanfaatkan dana eksternal sebagai sumber permodalannya dan memperoleh dana investor dengan menerbitkan saham serta memperdagangkannya di pasar modal (Puteri, 2011). Perusahaan yang tercatat pada Bursa Efek Indonesia digolongkan menjadi beberapa indeks saham. Salah satu indeks saham tersebut adalah indeks LQ 45.

Investor sebelum memutuskan untuk berinvestasi melihat beberapa faktor seperti faktor return dan risiko. Informasi sebanyak mungkin mengenai harga saham dan kinerja keuangan termasuk kebijakan yang digunakan perusahaan juga menjadi pertimbangan bagi investor dalam mengambil keputusan untuk berinvestasi. Salah satu kebijakan perusahaan yang sering menarik perhatian para investor adalah kebijakan dividen. Risk dan return merupakan fondasi utama dalam mempertimbangkan keputusan invetasi yang akan dilakukannya. Salah satu kebijakan perusahaan yang sering menarik perhatian investor yaitu kebijakan atas rasio deviden.

Kebijakan dividen merupakan salah satu keputusan penting dalam kaitannya dengan usaha untuk memaksimumkan nilai perusahaan yang berakibat pada pergerakan harga saham (Lapian, 2018). Kebijakan dividen merupakan keputusan apakah laba yang diperoleh perusahaan pada akhir tahun akan dibagikan kepada pemegang saham dalam bentuk dividen atau akan ditahan untuk menambah modal guna pembiayaan investasi di masa yang akan datang. Masing-masing perusahaan menetapkan kebijakan dividen yang berbeda-beda, karena kebijakan dividen berpengaruh terhadap nilai dalam membayar dividen kepada para pemegang saham. Besarnya nilai deviden yang akan diterima oleh para pemegang saham didasarkan atas kebijakan deviden yang ditetapkan oleh perusahaan.

Rasio pembayaran dividen diukur dengan menggunakan dividend payout ratio (DPR) dari perusahaan. Apabila rasio pembagian dividen menurun yang diakibatkan oleh menurunnya tingkat laba yang di hasilkan, perusahaan memilih untuk menahan cash out flow, dan hal ini akan mempengaruhi nilai deviden yang akan dikeluarkan oleh perusahaan. Berdasarkan teori signalling penurunan pembayaran dividen merupakan bad news atau sinyal negatif atas laba perusahaan, karena menunjukkan tanda bahwa laba yang diramalkan lebih kecil dibandingkan laba yang akan diperoleh, hal ini akan mempengaruhi 
demand atas saham dan korelasinya pada harga saham perusahaan yang bersangkutan.

Hubungan kebijakan deviden dan harga saham bukan suatu penelitian yang baru, sebelumya telah banyak yang menguji pengaruh langsung keduanya akan tetapi hasil penelitiannya inkonsistensi. Perbedaan yang dapat ditampilkan peneliti yang membedakan dengan penelitian sebelumnya adalah penggunaan provitabilitas sebagai variabel independent lainnya yang diduga dapat sebagai faktor lain yang dapat mempengaruhi pergerakan harga saham perusahaan. Profitabilitas dipilih sebagai variabel independent lainnya dan diproksikan menggunakan ROA, alasan penggunaan proksi ROA untuk memperlihatkan bagaimana kemampuan modal investasi yang menjadi bagian total aktiva akan memberi pertimbangan tambahan ketika proses upaya penetapan besaran deviden yang akan dibagikan pada pemegang saham. Profitabilitas sebagai variabel independent dikonfirmasikan melalui return on assets (ROA) menunjukkan kemampuan modal yang diinvestasikan dalam total aktiva untuk dipertimbangkan sebelum mengambil keputusan dalam upaya menetapkan besarnya dividen yang akan dibayarkan kepada para pemegang saham. Profitabilias merupakan kemampuan perusahaan untuk menghasilkan profit, dan dari profit inilah akan dijadikan dasar pertimbangan dari pembagian dividen. Apabila terjadi peningkatan rasio pembagian dividen maka harga saham perusahaan cenderung meningkat, namun hal tersebut dipertimbangkan dari nilai profitabilitas perusahaan.

Informasi merupakan unsur penting bagi investor dan pelaku bisnis karena informasi pada hakikatnya menyajikan keterangan, catatan atau gambaran baik untuk keadaan masa lalu, saat ini maupun keadaan masa yang akan datang bagi kelangsungan hidup suatu perusahaan. Teori ini dikemukakan pertama kali oleh Bhattacharya pada tahun 1979, signalling theory menjelaskan bahwa perusahaan yang berkinerja baik terdorong untuk memberikan informasi yang dapat bermanfaat bagi pasar, sehingga pasar diharapkan dapat membedakan perusahaan yang memiliki prospek yang baik dan buruk.

Isyarat atau signal merupakan tindakan yang diambil oleh manajemen untuk perusahaan yang memberikan petunjuk bagi investor tentang bagaimana manajemen memandang prospek masa depan (Bringham dan Houston 2001: 71). Informasi yang lengkap, relevan, akurat dan tepat waktu sangat diperlukan oleh investor di pasar modal sebagai alat analisis untuk mengambil keputusan investasi. Informasi yang dipublikasikan sebagai suatu pengumuman akan memberikan sinyal bagi investor dalam pengambilan suatu keputusan investasi. Jika pengumuman tersebut mengandung nilai positif, maka diharapkan pasar akan bereaksi pada waktu pengumuman tersebut diterima oleh pasar. Teori ini didasarkan pada asumsi bahwa terjadi asimetri informasi antara manajer dengan investor. Para manajer sering kali memiliki informasi yang lebih dibandingkan pemegang saham (Jensen, 1986). Menurut teori ini, dividen adalah salah satu cara mengurangi asimetri informasi atau ketidak-seimbangan informasi antara manajemen dan pemegang saham.

Teori sinyal juga menyatakan bahwa investor menganggap perubahan dividen sebagai isyarat dari perkiraan manajemen atas laba (Putri, 2018). Dalam hal ini, informasi pembagian dividen dapat diterima sebagai sinyal bagi investor 
dalam menilai perusahaan (Lashgari dan Ahmadi, 2014). Kenaikan jumlah dividen dianggap sebagai sinyal bahwa manajemen perusahaan meramalkan laba yang baik dimasa depan. Artinya pembayaran dividen yang tinggi merupakan sinyal positif, yang mengindikasikan prospek perusahaan yang menguntungkan (Deangelo et al., 2000: 4). Perusahaan yang memiliki laba yang tinggi juga merupakan sinyal bahwa perusahaan mempunyai prospek bagus dimasa yang akan datang (Pratiwi, 2017). Kenaikan rasio pembagian dividen seringkali menyebabkan kenaikan harga saham, begitu pula sebaliknya, penurunan rasio pembagian dividen umumnya menyebabkan penurunan harga saham (Barclay et al., 2014). Signaling hypothesis mendasari dugaan bahwa fluktuasi rasio pembagian dividen memiliki kandungan informasi yang akan direspon oleh pasar, dalam hal ini mempengaruhi minat investor untuk membeli atau menjual suatu saham, yang menyebabkan pergerakan pada harga saham tersebut. Informasi yang dipublikasikan sebagai suatu pengumuman akan memberikan sinyal bagi investor dalam pengambilan suatu keputusan investasi. Jika pengumuman tersebut mengandung nilai positif, maka diharapkan pasar akan bereaksi pada waktu pengumuman tersebut diterima oleh pasar.

Artinya pembayaran dividen yang tinggi merupakan sinyal positif, yang mengindikasikan prospek perusahaan yang menguntungkan (Deangelo et al., 2000: 4). Signaling hypothesis mendasari dugaan bahwa fluktuasi rasio pembagian dividen memiliki kandungan informasi yang akan direspon oleh pasar (Lashgari \& Ahmadi, 2014), dalam hal ini mempengaruhi minat investor untuk membeli atau menjual suatu saham, yang menyebabkan pergerakan pada harga saham tersebut (Legenzova et.al, 2017).

Teori dividen yang relevan atau sering disebut bird in the hand theory adalah teori yang dikembangkan oleh (Gordon \& Linter, 1969). Dalam teori ini Gordon dan Lintner menyatakan bahwa investor lebih menyukai dividen tunai daripada imbal hasil atas investasi (capital gain) di masa yang akan datang, karena menerima dividen tunai merupakan bentuk dari suatu kepastian dan pengurangan dari risiko. Dalam teori ini juga dijelaskan bahwa investor menghendaki pembayaran dividen yang tinggi dari keuntungan perusahaan sesuai tujuan utama investor yaitu menanamkan modal nya untuk mendapatkan keuntungan berupa dividen. Investor akan bersedia membayar harga yang lebih tinggi untuk perusahaan yang membayar dividen saat ini. Harapan pembayaran dividen saat ini terjadi karena ada anggapan bahwa mendapat dividen saat ini risikonya lebih kecil daripada mendapat capital gain di masa yang akan datang, meskipun capital gain yang akan didapatkan mungkin memberikan tingkat pengembalian yang lebih tinggi daripada dividen saat ini (Atmaja, 2008: 287).

Harga saham adalah harga saham yang terjadi di pasar bursa pada saat tertentu yang ditentukan oleh pelaku pasar. Nilai pasar ini ditentukan oleh permintaan dan penawaran saham bersangkutan di pasar bursa (Hartono, 2017: 130) Keberhasilan dalam menghasilkan keuntungan akan memberikan kepuasan bagi investor yang rasional. Harga saham yang cukup tinggi akan memberikan keuntungan, yaitu berupa capital gain dan citra yang lebih baik bagi perusahaan sehingga memudahkan bagi manajemen untuk mendapatkan dana dari luar perusahaan. Adapun jenis-jenis harga saham menurut Widoatmojo (2012: 54) adalah sebagai berikut; Pertama, harga nominal, adalah 
harga yang tecantum dalam sertifikat saham yang ditetapkan oleh emiten untuk menilai setiap lembar saham yang dikeluarkan. Besarnya harga nominal memberikan arti penting saham karena dividen minimal biasanya ditetapkan berdasarkan nilai nominal; Kedua, harga perdana, adalah harga yang terbentuk pada waktu saham tersebut dicatat dibursa efek. Harga saham pada pasar perdana biasanya ditetapkan oleh penjamin emisi (underwrite) dan emiten. Dengan demikian akan diketahui berapa harga saham emiten itu akan dijual kepada masyarakat biasanya untuk menentukan harga perdana; Ketiga, harga pasar, adalah harga jual dari investor yang satu dengan investor yang lain. Harga ini terjadi setelah saham tersebut dicatat dibursa. Transaksi yang terjadi di sini tidak lagi melibatkan emiten dari penjamin emisi. Harga ini yang disebut sebagai harga di pasar sekunder dan harga inilah yang benar-benar mewakili harga perusahaan penerbitnya, karena pada transaksi di pasar sekunder, kecil sekali terjadi negosiasi harga investor dengan perusahaan penerbit. Harga yang setiap hari diumumkan di surat kabar atau media lain adalah harga pasar; keempat Harga pembukaan, adalah harga yang diminta oleh penjual atau pembeli pada saat jam bursa dibuka. Bisa saja terjadi pada saat dimulainya hari bursa dan pada itu sudah terjadi transaksi atas suatu saham, kemudian harga terbentuk sesuai dengan yang diminta oleh penjual dan pembeli. Dalam keadaan demikian, harga pembukuan bisa menjadi harga pasar, begitu juga sebaliknya harga pasar mungkin juga akan menjadi harga pembukaan. Namun tidak selalu terjadi; Kelima, harga penutupan, adalah harga yang diminta oleh penjual atau pembeli pada saat akhir hari bursa. Pada keadaan demikian, bisa saja terjadi pada saat akhir hari bursa tiba-tiba terjadi transaksi atas suatu saham, karena ada kesepakatan antar penjual dan pembeli. Kalau ini yang terjadi maka harga penutupan itu telah menjadi harga pasar. Namun demikian, harga ini tetap menjadi harga penutupan pada hari bursa tersebut; Keenam, harga tertinggi, adalah harga yang paling tinggi yang terjadi pada hari bursa. Harga ini dapat terjadi transaksi atas suatu saham lebih dari satu kali tidak pada harga yang sama; Ketujuh, harga terendah, adalah harga yang paling rendah yang terjadi pada hari bursa. Harga ini dapat terjadi apabila terjadi transaksi atas suatu saham lebih dari satu kali tidak pada harga yang sama. Dengan kata lain, harga terendah merupakan lawan dari harga tertiggi; Kedelapan, harga rata-rata, merupakan perataan dari harga tertinggi dan terrendah.

Fluktuasi harga saham di pasar modal dapat dipengaruhi oleh beberapa faktor, baik faktor internal maupun faktor eksternal dari perusahaan. Menurut Brigham dan Houston (2010: 33) harga saham dipengaruhi oleh beberapa faktor utama yaitu faktor Internal, merupakan faktor dari dalam perusahaan yang dapat mempengaruhi fluktuasi harga saham, terdiri dari; pertama, pengumuman tentang pemasaran produksi penjualan seperti pengiklanan, rincian kontrak, perubahan harga, penarikan produk baru, laporan produksi, laporan keamanan, dan laporan penjualan; kedua, pengumuman pendanaan, seperti pengumuman yang berhubungan dengan ekuitas dan hutang; ketiga, pengumuman badan direksi manajemen (management board of director annnouncements) seperti perubahan dan pergantian direktur, manajemen dan struktur organisasi; keempat, pengumuman pengambilalihan diverifikasi seperti laporan merger investasi, investasi ekuitas, laporan take over oleh 
pengakuisisian dan diakuisisi, laporan investasi dan lainnya; kelima, pengumuman investasi seperti melakukan ekspansi pabrik pengembangan riset dan penutupan usah lainnya; keenam, pengumuman ketenagakerjaan (labour announcements), seperti negosiasi baru, kotrak baru, pemogokan dan lainnya; ketujuh, pengumuman laporan keuangan perusahaan, seperti peramalan laba sebelum akhir tahun fiskal dan setelah akhir tahun fiskal, earning per share, dividen per shere, price earning ratio, net profit margin, return on assets dan lain-lain.

Sedangkan faktor eksternal, merupakan faktor dari luar perusahaan yang dapat mempengaruhi fluktuasi harga saham suatu perusahaan, yang terdiri atas; pertama, pengumuman dari pemerintah seperti perubahan suku bunga tabungan dan deposito kurs valuta asing, inflasi, serta berbagai regulasi dan regulasi ekonomi yang dikeluarkan oleh pemerintah; kedua, Pengumuman hukum, seperti tuntutan terhadap perusahaan atau terhadap manajernya dan tuntutan perusahaan terhadap manajernya; ketiga, Pengumuman industri sekuritas, seperti laporan pertemuan tahunan insider trading, volume atau harga saham perdagangan pembatasan atau penundaan trading.

Kebijakan mengenai dividen mengacu kepada pilihan perusahaan apakah akan membagikan dividen dalam bentuk kas ataupun dalam bentuk lainnya, berapa besaran dividen yang akan dibagikan, dan seberapa sering dividen akan dibagikan. Apabila perusahaan memilih untuk membagikan laba sebagai dividen, maka akan mengurangi laba yang ditahan dan selanjutnya mengurangi total sumber dana internal (Ali et.al, 2017). Sebaliknya, jika perusahaan memilih untuk menahan laba yang diperoleh, maka kemampuan pembentukan dana internal akan semakin besar. Adapun beberapa istilah penting yang berkaitan dengan dividen diantaranya : tanggal pengumuman (declaration date), tanggal cum dividen (cum dividend date), tanggal ex-dividend (ex-dividend date), tanggal pencatatan (recording date), tanggal pembayaran dividen (dividend payment). Menurut PSAK 49 tentang akuntansi reksadana, pada ex-dividend date harga pasar dari saham yang tercatat bursa cenderung terpengaruh untuk turun karena pada saat itu, investor tidak lagi memiliki hak atas dividen yang diumumkan perusahaan. Pada umumnya saham yang sudah tidak mengandung dividen akan memiliki harga pasar yang relatif rendah daripada saham yang masih memiliki kandungan dividen. Untuk melihat perbedaan harga dapat dilihat pada saat $e x$-dividend date.

Pada saat ex-dividend date berlangsung, secara otomatis akan memberikan dampak pada harga saham karena pada saat tersebut investor telah kehilangan hak atas return dari dividen. Menurut(Cambell \& Beranek, 1959) pembagian dividen tunai akan mengakibatkan penurunan harga saham pada saat ex-dividend date. Lebih lanjut,(Michaely \& Villa, 1995) juga menyimpulkan bahwa harga saham jatuh pada waktu ex-dividend date, heterogenitas dan volume penjualan saham juga mengalami penurunan yang cukup drastis pula. Pada saat $e x$-dividend date investor pada umumnya memprediksikan, bahwa pembagian dividen akan berdampak pada harga saham. Prediksi ini didasarkan pada pemikiran logis, bahwa investor telah kehilangan hak atas return dari dividen. Investor yang berkeinginan mendapatkan keuntungan, cenderung akan memilih untuk tidak berada dalam posisi beli (long position). Dengan demikian harga saham tersebut akan mengalami penurunan sebanding dengan nilai dari return yang telah 
hilang. Adanya pemikiran tersebut akan mendorong harga atau nilai saham di pasar mengalami penurunan sampai mendekati nilai saat dividen diumumkan (Nurfadillah \& Nuzula, 2019). Oleh karena hal tersebut penelitian ini menggunakan closing price atau harga penutupan saat ex-dividend date untuk mengukur harga saham perusahaan.

Plus minus nilai DPR dapat mempengaruhi pengambilan putusan investasi bagi pemegang saham. Selain itu, hal tersebut mempengaurhi kondisi keuangan perusahaan dalam menjaga harga pasar saham (Dewi \& Putri, 2017). Peningkatan dividen yang dibayarkan dapat dianggap sebagai sinyal yang menguntungkan bagi investor dan para pemegang saham, sehingga menimbulkan reaksi harga saham yang positif (Andiani \& Gayatri, 2018). Pembayaran dividen oleh perusahaan merupakan informasi positif yang diterima oleh investor sehingga dapat mempengaruhi prilaku investor untuk membeli atau menjual saham mereka yang berakibat pada pergerakan harga saham.Penelitian sebelumnya yang dilakukan oleh Putri (2018), Mahmud (2017) dan Musiana, (2017) membuktikan bahwa kebijakan deviden yang dikeuarkan oleh perusahaan akan mempengaruhi pergerakan harga saham perusahaan tersebut. Kebijkan deviden dianggap efisien jika kebijakan yang dikeluarkan dapat mencapai keseimbangan antara deviden di masa kini dengan deviden di masa depan, hal ini diasumsikan akan mempengaruhi fluktuasi harga saham perusahaan yang bersangkutan. Maka hipotesis pertama $\left(\mathrm{H}_{1}\right)$ adalah kebijakan deviden berpengaruh positif pada harga saham..

Jumlah laba bersih kerap dibandingkan dengan ukuran kegiatan atau kondisi keuangan lainnya seperti penjualan, aktiva, ekuitas pemegang saham untuk menilai kinerja sebagai suatu persentase dari beberapa tingkat aktivitas atau investasi. Perbandingan ini disebut rasio profitabilitas (profitability ratio). Salah satu metode pengukuran profitabilitas yang digunakan dalam pnelitian ini adalah return on assets (ROA). Return on assets adalah satu rasio profitabilitas yang menunjukkan kemampuan perusahaan dalam memperoleh laba dari kekayaan atau aktiva yang digunakan. Rasio ini penting karena dapat mencerminkan kinerja keuangan dan kinerja operasional manajemen dalam memanfaatkan sumber daya yang dimiliki perusahaan.

Rasio provitabilitas diukur menggunakan proxi return on assets (ROA) bersifat positif atau searah artinya semakin tinggi nilai ROA yang ditunjukkan maka produktivitas perusahaan juga semakin baik ketika mencapai laba bersih berdasarkan pemanfaatan aset. Hal ini dapat diartikan bahwa semakin tinggi rasio ROA maka semakin baik produktivitas perusahaan dalam memperoleh keuntungan bersih melalui pemanfaatan asetnya. Hal ini tentunya akan meningkatkan kepercayaan dan daya tarik investor pada perusahaan. Peningkatan daya tarik pada perusahaan menjadikan perusahaan tersebut makin diminati investor, karena jika perusahaan memiliki profitabilitas yang tinggi maka tingkat pengembalian nya juga semakin tinggi. Hal ini juga akan berdampak pada fluktuasi harga saham dari perusahaan tersebut, jika profitabilitas (ROA) perusahaan semakin meningkat maka harga saham perusahaan akan meningkat akibat tingginya permintaan investor terhadap saham perusahaan. 
Profitabilitas memberikan pengaruh positif pada harga saham didukung oleh penelitian yang dilakukan oleh (Mustofa, 2013). (Atmaja, 2008) membuktikan juga bahwa besarnya nilai return on assets (ROA) yang ditunjukkan oleh perusahaan akan berpengaruh signifikan pada pergerakan kenaikan dan penurunan harga saham perusahaan yang bersangkutan. Maka hipotesis kedua $\left(\mathrm{H}_{2}\right)$ dalam penelitian ini adalah semakin meningkat profitabilitas perusahaan maka akan meningkatkan harga saham perusahaan.

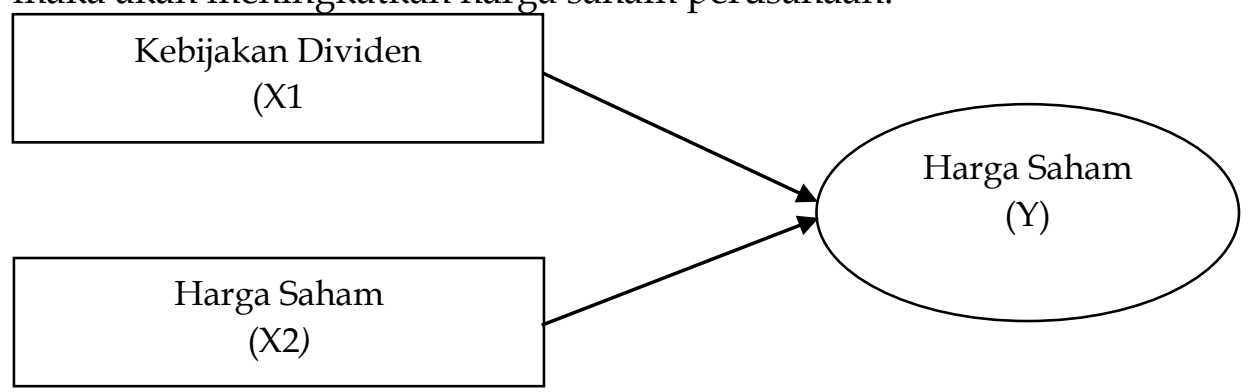

Gambar 1. Model Peneltian

Sumber: Data Penelitian, 2019

\section{METODE PENELITIAN}

Bentuk penelitian yang dipakai adalah asosiatif melalui pendekatan kuantitatif. Kebijakan deviden yang ditentukan oleh perusahaan, pegerakan turun naiknya harga saham, profitabilitas seluruh perusahaan yang terdaftar secara berturutturut di indeks LQ 45 untuk periode 2009-2018 merupakan objek penelitian yang dipilih oleh peneliti dalam penelitian ini. Data sekunder yang digunakan dalam penelitian ini adalah data yang dicatat secara sistematis yang berbentuk data runtut waktu ( time series data) yaitu dari tahun 2009-2018 yang bersumber dari laporan keuangan tahunan perusahaan dan laporan performa perusahaan yang tercatat pada indeks LQ 45 dengan mengakses www.idx.co.id dan www.ticmi.co.id. Populasi dalam penelitian ini adalah perusahaan yang terdaftar dalam LQ 45 selama tahun 2009-2018. Indeks LQ 45 dipilih karena emiten yang terdaftar pada indeks ini cenderung sering mendistribusikan dividen dan memiliki likuiditas perdagangan tertinggi, sehingga sahamnya banyak diminati investor, oleh karena itulah indeks LQ 45 sangat menarik untuk diteliti.

Perusahaan yang digunakan sebagai sampel penelitian adalah 6 perusahaan amatan berdasarkan indeks LQ 45 dengan menggunakan metode observasi nonpartsipan. Perusahaan amatan merupakan perusahaan yang tercatat secara berturut-turut pada indeks LQ 45 selama periode 2009-2018 dan sesuai dengan kriteria sampel. Sampel akan diambil dari populasi berdasarkan pendekatan probabilitas menggunakan teknik purposive sampling. Kriteria sampel yang pertama yaitu perushahaan tercatat pada indeks LQ 45 secara berturut-turut selama tahun pengamatan; kedua, perusahaan membagikan dividen secara berturut-turut pula selama periode pengamatan.

Teknik analisis data yang digunakan yaitu analisis statistik deskriptif yang terdiri dari uji asumsi klasik, analisis resgresi linear berganda, uji kelayakan model (uji f), uji koefisien determinasi $\left(R^{2}\right)$, dan pengujian hipotesisi menggunakan uji statistik $t$. 


\section{HASIL DAN PEMBAHASAN}

Analisis regresi linear berganda dapat menunjukkan arah hubungan antar variabel, apakah memiliki hubungan positif ataukah negatif dan digunakan untuk memecahkan rumusan masalah yang ada yaitu, melihat pengaruh antara dua variabel atau lebih. Pengujian Regresi Linear Berganda merupakan teknik yang digunakan untuk menguji pengaruhi langsung variabel X1 (kebijakan deviden) dan variabel $\mathrm{X} 2$ (profitabilitas) terhadap variabel $\mathrm{Y}$ (harga saham). Hasil pengujian ditunjukkan oleh Tabel 1 sebagai berikut:

Tabel 1. Hasil Regresi Linear Berganda

\begin{tabular}{cccccc}
\hline Model & \multicolumn{2}{c}{$\begin{array}{c}\text { Unstandardized } \\
\text { Coefficients }\end{array}$} & $\begin{array}{c}\text { Standardized } \\
\text { Coefficients }\end{array}$ & t & Sig. \\
\cline { 2 - 4 } & $\mathrm{B}$ & Std. Error & Beta & & \\
\hline (Constant) & 7,128 & 6,630 & & 1,138 & 0,260 \\
X $_{1}$ & 2,005 & 0.075 & 0,300 & 2,413 & 0,019 \\
X $_{2}$ & 1,150 & 0,277 & 0,202 & 1,628 & 0,039 \\
Adjusted R Square & & 0,210 & & \\
\multicolumn{2}{c}{ Sig. F } & & 0,003 & & \\
\hline
\end{tabular}

Sumber: Data Penelitian, 2019

Dilihat dari Tabel 1. Nilai constant sebesar 7,128 menunjukkan bahwa apabila nilai variabel kebijakan dividen $(X)$, dan provitabilitas $(\mathrm{M})$ sama dengan $0 \%$, maka harga saham perusahaan $(\mathrm{Y})$ mengalami kenaikan sebesar RP 7.128,00 per lembar saham. Nilai koefisien $\beta_{1}=2,005$ menunjukkan apabila nilai kebijakan dividen (X1) bertambah 1\%, maka harga saham perusahaan akan mengalami peningkatan sebesar Rp 2.005,00 per lembar saham dengan asumsi variabel bebas lainnya konstan. Nilai koefisien $\beta_{2}=1,150$ menunjukkan bahwa apabila nilai profitabilitas (X2) bertambah 1\%, maka harga saham perusahaan akan mengalami peningkatan sebesar Rp1.150,00 per lembar saham dengan asumsi variabel bebas lainnya konstan.

Nilai sig. uji $\mathrm{F}$ sebesar 0,003 < dari $a=0,05$ atau 5\% artinya bahwa model yang dipakai di dalam penelitian ini layak (fit) dilanjutkan diuji lebih lanjut sebagai dasar dalam penelitian. Adjusted $R^{2}$ sebesar 0,210 atau $21 \%$ vmerupakan nilai koefisien determinasi. Variabel kebijakan deviden (X1) dan profitabilitas (X2) mampu menjelaskan pergerakan kenaikan dan penurunan harga saham (Y), harga saham dalam penelitian ini dinilai dengan menggunakan proksi closing price saat ex-dividend date sebesar $21 \%$ dan sisanya (78\%) pegerakan harga saham dipengaruhi oleh faktor lain di luar model penelitian ini.

Variabel Kebijakan Dividen (X1) menunjukkan bahwa hipotesis pertama atau $\mathrm{H}_{1}$ diterima. Hal ini dibuktikan dengan nilai variabel kebijakan dividen (X1) memiliki nilai koefisien beta 2,005 dengan nilai signifikansi sebesar 0,019, nilai ini lebih kecil dari tingkat signifikansi yaitu 0,05. Hal ini memiliki arti bahwa kebijakan dividen berpengaruh positif signifikan terhadap harga saham. Salah satu pertimbangan investor dalam memutuskan untuk membeli saham dari suatu perusahaan adalah informasi pembagian dividen. Dengan pembagian dividen, selain investor mendapatkan keuntungan, investor juga dapat menilai prospek masa depan perusahaan. Dari hal itu dapat dilihat bahwa dividen menjadi sinyal untuk para investor menanamkan modalnya dalam bentuk saham. Hal tersebut sejalan dengan signalling theory yang menyatakan bahwa 
dividen sebagai isyarat dari prakiraan manajemen atas laba perusahaan (Bringham \& Houston, 2001: 71).

Hasil penelitian ini mendukung signaling theory. Informasi pembagian dividen mampu mengisyaratkan suatu signal atau informasi kepada investor untuk dapat menanamkan modalnya dalam bentuk saham. Dividen dianggap membawa informasi jika dividen menyebabkan laba atau keuntungan (Hartono, 2017: 576). Informasi kebijakan dividen perusahaan mengandung signal karena dapat mempengaruhi keputusan investasi investor untuk membeli saham suatu perusahaan yang berdampak pada peningkatan harga saham. Penelitian ini mendukung teori the bird in the hand yang artinya investor lebih menyukai mendapatkan keuntungan dari hasil investasi berupa dividen yang merupakan suatu kepastian walapun harus menunggu lebih lama namun memiliki risiko yang lebih kecil.Berdasarkan uraian tersebut, dapat disimpulkan bahwa tinggi rendahnya dividend payout ratio dapat menjadi pertimbangan para investor apakah akan menanam modal dalam bentuk saham pada perusahan atau tidak. Hasil penelitian ini sejalan dengan penelitian yang dilakukan oleh Musiana (2017), Istanti (2014), Silviana (2019), dan penelitian yang dilakukan oleh Putri (2016) menyatakan bahwa terdapat pengaruh yang signifikan antara kebijakan dividen terhadap harga saham.

Koefisien beta variabel provitabilitas (X2) sebesar 1,150 dengan nilai signifikansi sebesar 0,039 nilai ini lebih kecil dari tingkat signifikansi yaitu 0,05. Hal ini berarti bahwa profitabilitas perusahaan yang di proksikan dengan return on assets (ROA) berpengaruh positif signifikan terhadap harga saham perusahaan. Dalam hal ini investor sebelum memutuskan untuk berinvestasi memperhatikan kinerja efisiensi keuangan perusahaan melaui ROA. Semakin tinggi nilai ROA menunjukkan semkain efisien perusahaan dalam mengelola asetnya untuk mendatangkan laba, sehingga dapat menarik investor untuk membeli saham pada perusahaan tersebut. Begitu juga sebaliknya, apabila ROA semakin kecil, dapat disebabkan oleh banyaknya asset perusahaan yang tidak dimanfaatkan, investasi dalam persediaan yang terlalu banyak dan menunjukkan rendahnya efisiensi perusahaan, sehingga mendorong investor untuk menjual saham yang mereka miliki. Djhshdjds hsdkhjsdh dsjfhsdh ksdhfh

Hasil penelitian ini juga mendukung signaling theory, yang menyatakan bahwa ada suatu informasi yang dapat mengakibatkan pasar bereaksi. Dalam hal ini informasi perubahan baik itu berupa peningkatan maupun penurunan profitabilitas yang dilhat melalui return on assets ROA pada suatu perusahaan merupakan suatu informasi atau signal yang dapat mengakibatkan investor menjual ataupun membeli saham suatu perusahaan dan berakibat pada fluktuasi harga saham perusahaan tersebut. Hasil penelitian ini sejalan dengan penelitian yang dilakukan oleh Halimatusakdiah (2013), Novariza (2010) dan penelitian yang dilakukan oleh Rista (2011) yang menyatakan bahwa return on assets berpengaruh secara signifikan terhadap harga saham.

Penelitian ini dilakukan untuk mengetahui perkembangan harga saham melalui, kebijakan dividen, kinerja profitabilitas, serta untuk mengkaji pengaruh kebijakan dividen terhadap harga saham dengan profitabilitas sebagai variabel pemoderasi pada emiten LQ45 dalam waktu pengamatan 10 tahun yang terdiri dari tahun 2009 sampai dengan tahun 2018. Berdasarkan hasil pembahasan yang 
telah diuraikan pada bab sebelumnya, maka dapat di tarik kesimpulan sebagai berikut; Pertama, kebiajakan dividen yang diproksikan dengan dividend payout ratio (DPR) berpengaruh secara signifikan terhadap harga saham. Besar kecilnya perubahan rasio pembagian dividen perusahaan dapat mengakibatkan perubahan yang searah terhadap harga saham; Kedua, profitabilitas yang diproksikan dengan return on assets (ROA) menunjukkan perpengaruh yang signifikan positif terhadap harga saham. Hal ini menunjukkan setiap perubahan rasio profitabilitas perusahaan akan mengakibatkan perbuahan atau fluktuasi terhadap harga saham.

\section{REFERENSI}

Ali, A., Sharif, I., \& Jan, F. A. (2017). Effect of Dividend Policy on Stock Prices. Journal of Management Info, 4(1), 19-28. https:/ / doi.org/10.31580/jmi.v6i1.47

Andiani, N. W. S., \& Gayatri. (2018). Pengaruh Volume Perdagangan Saham, Volatilitas Laba, Dividend Yield, Dan Ukuran Perusahaan Pada Volatilitas Harga Saham. 24, 2148-2175.

Anggraini Putri, E. (2015). Pengaruh Kebijakan Dividen, Kebijakan Hutang Dan Profitabilitas Terhadap Nilai Perusahaan Manufaktur Yang Terdaftar DI Bursa efek Indonesia. JOM FISIP (2018), 5(1) 1-18.

Atmaja, L. S. (2008). Pengaruh Profitabilitas, Likuiditas dan Deviden Per Share Terhadap Harga Saham Perusahaan LQ-45 Yang Terdaftar Di Bursa Efek Indonesia. Journal of Chemical Information and Modeling. https://doi.org/10.1017/CBO9781107415324.004

Brigham, \& Houston. (n.d.). Pengaruh kebijakan dividen, volume perdagangan, earning volatility, leverage, dan firm size terhadap volatilitas harga saham perusahaan lq45. 7, 761-771.

Bringham, \& Houston. (2001). Dividend policy.

Cambell, \& Beranek. (2006). Pengaruh Pengumuman Deviden terhadap Perubahan Harga Saham Sebelum dan Sesudah Ex-Deviden Date di Bursa Efek Jakarta (BEJ). Jurnal Akuntansi Dan Keuangan, 8(2), 71-77.

Deangelo, H. (2000). Special Dividens and the Evolution of Dividend Sygnaling. Economic and BUsiness Journal, Marshall School of Business, 2(2). Retrieved from dskinner@umich.edul

Dewi, P. R. A., \& Putri, I. G. A. . A. D. (2017). Pengaruh kebijakan Dividen Pada Nilai Perusahaan Dengan Pengungkapan CSR Dan Good Corporate Governance Sebagai Pemoderasi. 21.1, 173-199.

Hartono, Y. (2017). Analisis Portofolio Saham.

Istanti, S. L. W. (2014). Pengaruh Kebijakan Dividen Terhadap Harga Saham Pada Perusahaan LQ 45. Jurnal Ilmiah Manajemen POTENSIO STIE YPPI Rembang, 3, 1829-7978. Retrieved from http://journal.stieyppi.ac.id/index.php/potensio/article/view/44/41

Lapian, Y. (2018). Peran Kebijakan Dividen Dalam Memediasi Pengaruh Profitabilitas dan Leverage Terhadap Harga Saham Pada Perusahaan Manufaktur. E-Jurnal Manajemen Unud, 7(2), 816-846. Retrieved from https:// doi.org/10.24843/EJMUNUD.2018.v7.i02.p10\%0AISSN

Lashgari, Z., \& Ahmadi, M. (2014). The Impact of Dividend Policy on Stock Price Volatility in the Tehran Stock Exchange. Kuwait Chapter of Arabian Journal of 
Business and Management Review, 3(10), 273-283. https://doi.org/10.12816/0018408

Legenzova, R., Jurakovaite, O., \& Galinskaite, A. (2017). The analysis of dividend announcement impact on stock prices of baltic companies. Central European Business Review, 6(1), 61-75. https:/ / doi.org/10.18267/J.CEBR.173

Linter, G. (1969). Analisis Harga Saham Sebelum Dan Sesudah Ex-Dividend Date Analisis Harga Saham Sebelum Dan Sesudah Ex-Dividend Date.

Mahmud, M. (2017). Pengaruh Kebijakan Dividen Terhadap Harga Saham Pada Perusahaan LQ 45 Yang Terdaftar Di Bursa Efek Indonesia ( BEI ) Periode 2013-2017. Jurusan Akuntansi Fakultas Ekonomi Universitas Negeri Gorontalo, 4(4), 553-569. Retrieved from http://jurnal.ideaspublishing.co.id/index.php/ideas/article/view/129

Michaely, \& Villa. (1995). Journal of Chemical Information and Modeling, 53(9), 16891699. https://doi.org/10.1017/CBO9781107415324.004

Mulyana Putri, M. (2016). Pengaruh Kebijakan Dividen Terhadap Harga Saham Dengan Profitabilitas Sebagai Variabel Moderating Pada Emiten LQ45 NonPerbankan Periode 2014-2016. Journal of Chemical Information and Modeling, 53(9), 1689-1699. https:/ / doi.org/10.1017/CBO9781107415324.004

Musiana. (2017). Analisis Pengaruh Likuiditas dan Kebijakan Dividen Terhadap Harga Saham Pada Perusahaan Badan Usaha Milik Negara (BUMN) Yang Terdaftar Di Bursa Efek Indonesia (BEI) Periode 2010-2015. 6, 5-9.

Mustofa, G. (2013). Pengaruh Returnon Equity ( Roe ) Dan Return on Asset ( Roa) Terhadap Harga Saham Perusahaan Manufaktur Sektor Makanan Dan Minuman Yang Terdaftar Di Bursa Efek Indonesia Tahun 2010-2012 Stock Price of Companies Manufacturing Food and Beverage Sector. 1-11.

Novariza. (2010). Lembar pengesahan. Universitas Stuttgart.

Nurfadillah, L. F., \& Nuzula, N. F. (2019). Analisis Dampak Ex-dividend date Pada Pembayaran Dividen Terhadap Abnormal Return ( Studi Pada Perusahaan yang Terdaftar dalam Indeks IDX High Dividend 20 Tahun 2018 ). 72(1), 91-99.

Puteri, U. A. (2011). Analisis pengaruh sumber pendanaan internal dan eksternal terhadap kemampuan perusahaan keluarga berinvestasi.

Putri, I. K. (2018). Pengaruh Kebijakan Dividen terhadap Harga Saham (Studi pada Perusahaan pertambangan di Bursa Efek Indonesia). 01(01), 8-15.

Rista. (2011). pengaruh likuiditas, EPS, dan ROA terhadap harga saham pada perusahaan Wholesale and Retail Trade yang terdaftar di BEI tahun 2006-2009. 